\title{
Da'wah Patterns in Developing Religious Harmony in Semarang City
}

\author{
Siti Prihatiningtyas ${ }^{1 *}$, Siti Sholihati ${ }^{2}$ \& Lukmanul Hakim ${ }^{3}$ \\ ${ }^{123}$ UIN Walisongo, Semarang, Indonesia \\ *siti.prihatiningtyas@walisongo.ac.id
}

\begin{abstract}
This study aims to find the format of the pattern of developing religious harmony and the role of government and religious leaders in creating a conducive situation in Semarang. The research uses a qualitative approach. Data were collected through observation, interview, and documentation techniques. The results of this study indicate that the city of Semarang consists of various tribes, religions, and ethnicities, the people have a high sense of tolerance. This is due to the community's spiritual condition and the mindset of an advanced society due to many universities. Communication and cooperation are well established between government figures, religious leaders, and community leaders in various community harmony forums and organizations such as Petamas and FKUB. The forum can be used as a medium for dialogue. From the researcher's analysis, harmonization in religious harmony is influenced by activities that create and touch a sense of togetherness and affection. The pattern of social da'wah is an alternative in building tolerance and harmonization over the plurality of society.
\end{abstract}

Keywords: development pattern; religious harmony; social da'wah; Semarang city

\begin{abstract}
ABSTRAK
Penelitian ini bertujuan untuk menemukan format pola pengembangan kerukunan beragama dan peran para pemimpin pemerintahan dan agama dalam mewujudkan situasi kondusif di Kota Semarang. Penelitian menggunakan pendekatan kualitatif. Data dikumpulkan melalui teknik observasi, wawancara, dan dokumentasi. Hasil penelitian ini menunjukkan bahwa kota Semarang terdiri dari berbagai suku, agama, dan etnis, masyarakatnya memiliki rasa toleransi yang tinggi. Hal tersebut disebabkan kondisi masyarakatnya agamis, dan pola pikir masyarakat yang maju karena banyaknya perguruan tinggi. Komunikasi dan kerjasama terjalin dengan baik antara tokoh pemerintahan, tokoh agama, dan tokoh masyarakat yang terwadahi dalam forum dan organisasi kerukunan umat beragam seperti Petamas dan FKUB. Forum tersebut dapat dijadikan sebagai media dialog. Dari analisis peneliti harmonisasi dalam kerukunan umat beragama dipengaruhi oleh kegiatan-kegiatan yang menimbulkan dan menyentuh rasa kebersamaan dan kasih sayang antar sesama. Pola dakwah sosial menjadi alternatif dalam membangun toleransi dan harmonisasi di atas kemajemukan masyarakat.
\end{abstract}

Kata kunci: pola pengembangan; kerukunan beragama; dakwah sosial; Kota Semarang.

Received: Oktober 2021. Accepted: November 2021. Published: Desember 2021. 


\section{INTRODUCTION}

Indonesia has a variety of identities that are different from one another. Socially, this diversity gives birth to pluralism and multiculturalism. Namely, a diverse condition caused by differences in ethnicity, race, religion, culture, and even political perspectives. If this diversity is not managed carefully, friendly, and full of wisdom, it has the potential to trigger tension, even social conflict. This narrative is the main point in this research, which tries to analyze the pattern of developing religious harmony as part of Islamic da'wah in the context of syumbiyyah wa qabailiyyah (Aripudin \& Sambas, 2012; Aripudin 2013).

Da'wah activities aim to form a believing human person. This is done through a series of activities that lead to amar maruf nabi munkar. Da'wah is the foundation in building the values of human consciousness both theologically and sociologically. The internalization of the values of Islamic teachings must be transformed into the reality of human life both on a personal, family, social group, and even state scale (Mulkhan, 1996). Islamic da'wah displays the universality of Islamic teachings as a comprehensive system for the universe (rabmatan lil alamin).

The era of globalization raises the dynamics of da'wah, which is quite significant. This is marked by a shift in Islamic da'wah activities that use not only conventional channels but also digital technology as a medium of da'wah. This dynamic gives birth to various threats and challenges that occur in almost all aspects of human life. The impact of digital industrialization has the potential to threaten social harmony. This is related to the trend of using digital media platforms in human activities to fulfill economic, social, educational, cultural, political, and even religious interests (Rustandi \& Muchtar, 2020).

One of the digital threats that affect the dimension of human religiosity is the phenomenon of spreading manipulative and provocative information (hoax, hate speech). This information dissemination flooded the digital media timelines used by the public. Data from APJII (2020) stated that the spread of hoax and hate speech information throughout 2019-2020 was dominated by news about politics, health, and religion. Religion is a sensitive issue often used by certain groups to create friction in society. This is even more worrying when using digital media platforms as a channel for disseminating information that aims to destroy social harmony. 
The stagnation of social communication channels can cause social phenomena that lead to disintegration. Conflicts in the community begin because of a misunderstanding in perceiving something. This is growing when the loss of consciousness as a human being who is part of a social community. Differences in ethnic backgrounds, religions, races and social groups or groups are used as triggers to damage the social cohesiveness of society. This is a sensitive issue that is vulnerable to being exploited for specific interests that lead to the division or disintegration of the nation.

The da'wah perspective views social reality as a field of da'wah, a space for actualizing Islamic values. The phenomenon of intolerance and social disharmony is a da'wah challenge that must be addressed as a social dynamic. In this case, Islamic da'wah is carried out to strengthen the joints of social life so that it is in harmony with the values of Islamic teachings. Islamic da'wah is oriented inward, for Muslims internally and outwardly, which places humans as objects of Islamic da'wah (Muhyiddin et al., 2014).

Da'wah's reality displays the diversity of da'wah objects based on differences in geographical, social, educational, economic, cultural, and political backgrounds. The reality of this diversity as a sunnatullab is a challenge for every subject of da'wah in planning, implementing, fostering, and supervising the da'wah activities they do. In other words, Islamic da'wah as a channel to display Islam that is rahmatan lil alamin must touch various social layers of society so that the transmission of Islamic teachings is transformed in the reality of people's lives (Rustandi \& Hanifah, 2019).

The problems of Islamic da'wah related to the reality of da'wah's object in a plural and multicultural manner, namely the potential for social disharmony. This is marked by the presence of intolerance behavior that undermines inter-religious harmony. The disharmony between religious adherents is usually based on prejudice against one another. This prejudice arises due to misunderstandings in understanding religious texts, the absence of mutual understanding, and the existence of external interests that ignite the emotions of religious adherents so that it leads to conflict (Suryana, 2011; Masmuddin, 2018).

Da'wah symubiyyah wa qabailiyyah aims to display an attitude of religious moderation in society's dimensions of plurality and multiculturality. In this case, religious harmony becomes a strategic da'wah discourse that must be carried out as an effort to actualize peaceful and tolerant Islamic teachings (Setiawati, 2012). The da'wah agenda based on religious moderation is carried out to answer the challenges of da'wah in 
the dimension of mercy. The da'wah of mercy is oriented to implementing exemplary-based da'wah displayed by the Prophet Muhammad in carrying out the expansion of Islamic da'wah. The Medina Charter is authentic evidence in Islamic da'wah's history that can be used as a reinforcement in narrating moral and humanitarian tolerance based on Islamic values (Rustandi \& Sahidin, 2019).

The da'wah pattern based on religious moderation is carried out on the foundation of universal Islamic teachings. In this case, diverse moderation is seen as an attitude of balance in understanding and practicing Islamic teachings in the context of worship and muamalah. Religious moderation is paired with the term wasathiyyah. This term was popularized by Yusuf Al-Qardhawi, who described a balanced attitude in the actualization of Islamic teachings, where the four elements of religious moderation include honesty, openness, compassion, and flexibility (Mussafa, 2018).

Religious moderation is seen as a moderate attitude in actualizing Islamic teachings that accommodate diversity (Busyro, Aditya \& Adlan, 2019). This attitude is based on tasamuh and tawazun in instilling the values of tolerance and social harmony (Kosasih, 2019). In da'wah activities, the concept of religious moderation can be used as a da'wah strategy that is carried out by taking into account the condition of the diversity of da'wah objects, both in terms of religious understanding, socio-educationalcultural background, political point of view, and affiliation of da'wah organizations (Kusnawan \& Rustandi, 2021). Thus, the pattern of da'wah based on the attitudes and values of religious moderation can be used as an alternative in disseminating Islamic messages with heterogeneous targets of da'wah objects where this da'wah is carried out with an external expansion orientation that targets humans in general as the object of Islamic da'wah.

The practice of freedom of religion and belief as part of the construction of relations between religion and the state in Indonesia still leaves many problems. State institutions are the ones that commit the most violations of freedom of religion and belief (Fidiyani, 2013). A view is conveyed by Arafah \& Basman (2021) that:

"The roots of suspicion towards others are deeply rooted in several religious groups. Some of these denominational traditions are characterized by isolationism, confrontation (seeing different religions as rivals to be conquered), and hatred. Every religious adherent tends to power so that the boundary between the interests 
of power and religiosity is fragile."

The Indonesian Ministry of Religion's Research and Development and Education Agency (2001) conducted research and mapping of religious harmony in 2001 in twelve provinces in Indonesia. This study presents cases with nuances of SARA (Ethnicity, Religion, Race, and Intergroup) in the reform era. In this era, group egoism, regionalism, ethnic fanaticism, and religion emerged, resulting in many mass riots. This research was designed from the start to recruit the values of harmony to ward off the potential for disintegration between components of society.

This research was continued by the Research and Development Agency and Religious Education and Training Ministry of the Republic of Indonesia (2002) by analyzing the incidents of riots, tensions, and social conflicts in Indonesia. This event reappears elsewhere or maybe in the same place with a conflict model similar to the previous event. There are nine riots and social conflicts that are horizontal and vertical, which are used as case studies in this research. It is called horizontal because the riots have ethnic, religious, and racial nuances to focus on the symbols of these three aspects. Meanwhile, it is said to be vertical because this model of rioting has a class nuance, with the target of mass riots being upper-class groups. This upper-class group can be economical or political.

Another study was conducted by Gunaryo Achmad (2007), who discussed mediation, conflict resolution, and peacebuilding in the Indonesian context. This research is part of an effort to provide information to the public regarding the importance of mediation as an alternative to conflict and dispute resolution. Furthermore, Alo Liliweri's (2009) research contains the mapping of multicultural policies implemented in Indonesia. This study tries to analyze the patterns and models of social conflict. The research was conducted by first introducing the concepts of ethnicity and race and making ethnicity and race into self-identity, social identity, and cultural identity. In addition, the concepts of majority and minority groups related to religion, ethnicity, and other groups are analyzed concerning plural society. This study discusses the concepts of social prejudice, then discusses the causes of conflict and how the conflict resolution process is carried out.

Contextually, research on da'wah and religious harmony is carried out by taking the research locus in several regions in Indonesia. For example, Rahmini Hadi's research (2016) analyzes patterns of religious harmony in the Banyumas area. It is concluded that the harmonization of religious 
harmony occurs for several reasons, including tolerance, cultural action, and understanding of noble values. Manshuruddin's research (2017) analyzes patterns of religious harmony through the Religious Harmony Forum (FKUB) in North Sumatra. The results showed that the pattern of harmony was carried out through theological dialogue, social interaction, advocacy, regulation, and interactive dialogue. Masmuddin's research (2018) analyzes da'wah in realizing inter-religious interaction and harmony in Palopo, South Sulawesi. It was concluded that Islamic da'wah aims to build understanding so that communication and social harmony can be established both internally and externally.

Contextually, research on da'wah and religious harmony is carried out by taking the research locus in several regions in Indonesia. For example, Rahmini Hadi's research (2016) analyzes patterns of religious harmony in the Banyumas area. It is concluded that the harmonization of religious harmony occurs for several reasons, including tolerance, cultural action, and understanding of noble values. Manshuruddin's research (2017) analyzes patterns of religious harmony through the Religious Harmony Forum (FKUB) in North Sumatra. The results showed that the pattern of harmony was carried out through theological dialogue, social interaction, advocacy, regulation, and interactive dialogue. Masmuddin's research (2018) analyzes da'wah in realizing inter-religious interaction and harmony in Palopo, South Sulawesi. It was concluded that Islamic da'wah aims to build understanding so that communication and social harmony can be established both internally and externally.

Furthermore, Abdul Jamil Wahab's research (2019) tried to find a model of religious harmony in Susuru Hamlet, Ciamis, West Java. This hamlet is a tolerant area inhabited by religious communities from Islamic, Catholic, Christian, and Penghayat groups. The portrait of religious harmony in this hamlet can be found in several socio-religious activities such as establishing houses of worship, appreciation of religious worship, and tolerance of humanity. Sabara's research (2019) photographed religious harmony in Ohoidertawun Village, Southeast Maluku Regency. This village is inhabited by Islamic, Catholic, and Christian backgrounds. The portrait of religious harmony is carried out in social activities based on local wisdom. It becomes a social mechanism in building social resilience and a moderation approach in religion. Research by Sabarudin and Mahmud Arif (2019) took Loloan Village, Jembrana, Bali, to photograph religious harmony. Most Muslims inhabit Loloan village during the Hindu solid 
community in Bali. It is concluded that the local wisdom approach becomes a node that strengthens the interfaith social order for the Loloan community.

Based on some of the research above, this study aims to analyze da'wah's pattern in building religious harmony in the city of Semarang. In addition, the research was conducted to look for formats or patterns developed by government leaders, religious leaders, and community leaders in Semarang City in reducing conflicts, both horizontally and vertically. The research is also directed to analyze the role of government leaders, religious leaders, and community leaders in creating a conducive situation in Semarang.

Demographically, Semarang City has a diverse population that can conflict. However, the reality shows that in Semarang, there are rarely social conflicts with SARA nuances. This, of course, cannot be separated from the role of all components of society in maintaining social integrity and cohesiveness. Therefore, this study was conducted to analyze the pattern of religious harmony in Semarang City. Thus, it is hoped to provide significant contributions and benefits to the conceptual and practical development process in mapping religious moderation-based da'wah.

The results of this study are expected to be helpful for all groups. Both theoretically and practically significant for government, religious, and community leaders. Theoretically, this research helps develop academic concepts related to the socio-religious mainstream. Practically, this research is helpful for policymakers, community leaders, and community leaders to resolve conflicts with religious nuances.

Religious harmony is a harmonious and dynamic relationship and peace between religious people in Indonesia. This includes inter-religious relations, relations between people of different religions, and inter-religious relations and the government. This relationship was built to strengthen national unity and increase charity to build a prosperous community together (Dachlan, Noviani, \& Mustolehudin, 2018).

This study uses a qualitative approach, which is an approach that is used as a research procedure that produces descriptive data. With this approach, it is hoped that it will describe the patterns of developing religious harmony in the city of Semarang. Data were collected through interviews, observation, and documentation techniques. Researchers searched for data from several informants in related institutions, namely the Semarang City Information and Communication Office, the National 
Siti Prihatiningtyas, Siti Solihati \& Lukmanul Hakim

Unity and Community Protection Agency (Kesbanglinmas), Semarang City, Semarang City Central Statistics Agency, Semarang City Religion Department, Community Communication Forum Religion (FKUB) Semarang City, Indonesian Ulema Council (MUI) Semarang City, nonIslamic institutions such as Walubi, Indonesian Church Association, and so on.

The documentation method is carried out by obtaining official archives from government institutions and the Ministry of Religion. The data was then analyzed using the inductive method. This analytical method is used to study and analyze empirical facts in the field. With empirical facts, conclusions can be drawn or generalizations from problems that occur in the field naturally according to the research topic. Data were analyzed through data reduction stages by selecting and categorizing data according to the research focus, then presented and verified to conclude the pattern of da'wah in the development of religious harmony.

\section{RESULT AND DISCUSSION}

\section{Harmonization of Religious Harmony in Semarang City}

Diversity includes differences in culture, religion, race, language, ethnicity, tradition, etc. There are often tensions and conflicts between cultural groups in a multicultural society. Thus, this condition impacts the harmony of life (Akhmadi, 2019). In the era of regional autonomy, Semarang, as the capital of Central Java Province, has progressed quite rapidly. Although the majority of the people of Semarang City adhere to Islam (85.84\%), they live in harmony with non-Muslim communities (14.16\%) (Imron, 2011). Various ways have been done to foster religious harmony in the community. It is just that the complexity of the problem of religion itself has made the solution so complicated. The implementation of pluralistic religious education in schools, especially in public universities, is considered capable of resolving disputes between religious communities (Marzuki, 2016).

The results of a 2019 Ministry of Religion survey showed that the Religious Harmony Index (KUB) in Indonesia was 73.83 percent. Several factors strengthen religious harmony, among others, because of the correlation between education, income, and the role of the Ministry of Religion on harmonious attitudes in Indonesia (Sila \& Fakhruddin, 2020). Figure 1 below shows the Religious Harmony Index according to the Ministry of Religion in 2019. 
Figure 1. Religious Harmony Index (KUB)

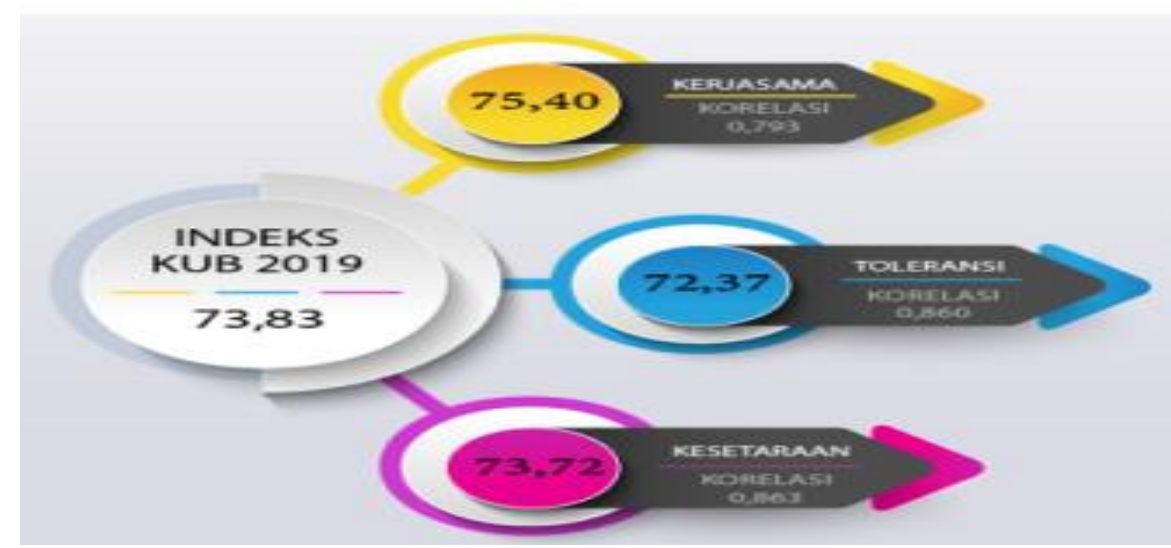

Source: Sila \& Fakhruddin, 2020

Based on Figure 1 above, there are several significant findings regarding religious harmony, namely: (1) Semarang City as the capital of Central Java province, which consists of various tribes, religions, and ethnicities, where the community has a high sense of tolerance caused by conditions the community is religious, and the mindset of the community is advanced due to a large number of universities; (2) The establishment of good communication and cooperation between government figures, religious leaders, and community leaders who are accommodated in religious harmony forums and organizations such as Petamas and FKUB. The forum can be used as a medium for inter-religious dialogue, and (3) The realization of harmonious conditions in religious harmony is influenced by activities that create and touch a sense of togetherness and love, among others.

Life in a society consisting of various religions, ideologies, cultures, unequal levels of education, social strata, and economics is sunnatullah. These differences it has the potential to cause harmful social interactions. Prejudice can arise at any time and has the potential to spread the scent of suspicion and sentiment. So it has the potential to cause social conflict. A conflict is a natural conflict generated by individuals or groups because those involved have different attitudes, beliefs, values , or needs (Liliweri, 2005). Regarding the issue of religious conflicts, Peter Suwarno stated that conflicts often occur more because of the absence or lack of development of interfaith communication platforms. Therefore, it is essential to 
campaign for inter-religious dialogue and sincerity in participating (Musahadi, Ed., 2007:23).

The sociological perspective views that it is essential to maintain openness and productive dialogue between religious adherents in any situation and condition. So that it can maintain the creation of harmonization and harmony between religious communities, this can be realized if all components of society collaboratively continue to establish intensive communication. As a big city with various advantages and disadvantages, the city of Semarang has the potential for conflict. However, because government leaders, religious leaders, and community leaders can establish friendship and intensive communication, the potential for conflict and mass riots can be eliminated and prevented.

Based on observations, several problems that often arise in the city of Semarang are related to the establishment of places of worship. This is due to several reasons, among others: First, there are multiple interpretations of the Joint Regulations of the Minister of Religion and the Minister of Home Affairs Numbers 9 and 8 of 2006, particularly articles 13 and 14; Second, the lack of clarity on the requirements for the establishment of places of worship as regulated in the Joint Regulations; and Third, the community, in this case, the followers of religion, do not understand the legal rules that apply in the establishment of places of worship. Good communication between the government and community components can continuously be used as an alternative to reduce conflict. In addition, through communication, religious leaders are required to awaken and enlighten their people to understand that differences are grace. Continuous communication with a clear agenda needs to be mediated by the government as the holder of development policies in Semarang.

The Semarang City Government has intensively held activities involving religious and community leaders. This is the power of social harmony that can evoke the spirit of togetherness, collectivity, and collaboration. To strengthen the conduciveness of the community. For example, in August 2007, the Semarang City Government held a joint prayer involving religious leaders. This is an effort to strengthen the spirit of cooperation and tolerance to strengthen solidarity and social cohesiveness. The holding of collective prayer is seen as a positive step that must always be carried out at certain moments on an ongoing basis. The point of awareness is that differences of opinion among religious people will always arise and sometimes can cause division. So it is necessary to 
conduct intensive dialogue to strengthen awareness to unite. Interactive dialogue is carried out to create social harmony (Manshuruddin, 2017).

The system and institutional approach is carried out by forming a Government Association, Religious Leaders and Community Leaders (Petamas), and the Religious Communication Forum (FKUB). This approach has made a significant contribution in maintaining conduciveness and harmonization of religious harmony. One of the most dominant factors driving the maintenance of inter-religious harmony in Semarang is the high awareness of the religion embraced by each ummah with the faith that is lived correctly. The coaching process is carried out simultaneously and in a network through this approach. Every religious figure builds social awareness and tolerance internally and strengthens the relationship of cooperation externally (Masmuddin, 2018).

In addition, the harmonization of religious harmony in the city of Semarang is realized because it is influenced by the high awareness of the community in the aspect of education. In this case, applying ethics and community life values that respect and appreciate each other strengthens the spirit of togetherness. The majority of people have and uphold high religious values. This is inseparable from the history of establishing the City of Semarang, which leaders led from religious backgrounds. Therefore, his government's development vision aims to make Semarang a religious metropolis.

The people believe several religious norms and values of Semarang City to become a solid glue base for creating inter-religious harmony. These norms and values include: First, belief and trust in God Almighty. This belief understands that man belongs to Allah and Him will surely return. With this belief, as the caliph of Allah on this earth, every human being is obliged constantly to do good to anyone regardless of ethnicity, religion, race, or between groups.

Second, the belief that humans must be honed, loving, and nurturing each other. This means that humans need each other in all aspects of life. Therefore, it is necessary to have mutual respect and help and remind each other to realize inner and outer prosperity in peaceful community life. Third, there is a belief based on religion and the philosophy of human life that anyone who does something terrible will reap the consequences in the order of social life. Furthermore, whoever does goodwill gets a reward commensurate with his good deeds regardless of anyone, religion, ethnicity, and wherever he comes from. 
The social norms of the religious value stated above are very pronounced in coloring the social life in the city of Semarang. So that this can prevent the disintegration of the nation, especially regarding the relationship between religious communities. So far, community cooperation in Semarang has continuously developed well. This is because religious adherents understand not to hurt their respective religious feelings. On the other hand, inter-religious communities complement and cooperate to be mutually beneficial for social life.

As for the harmonization of religious harmony, it is carried out through three forms of activity, namely: First, there is a sense of community tolerance related to differences; Second, tolerance is formed by sociocultural actions that can be realized through dialogue and meetings between figures and social approaches as part of society; and Third, tolerance is created through understanding noble values, although there are sides that turn global. Cultural values for dialogue that lead to mutual respect can be a shaper of peace (Hadi, 2016).

The da'wah perspective views that the process of realizing the harmonization and harmony of religious communities is carried out with the value of tolerance through bil hal education (education with behavior and actions), bil maqol education (education through oral and tradition), and bil $d u^{\prime} a$ education (education with prayer) (Yusrina \& Ma'arif, 2020). In this case, exemplary is the key to fostering people to follow the values of goodness in da'wah. These values of togetherness can be established between followers of every religion if they are carried out by prioritizing the principles of openness, deliberation, tolerance, honesty, and togetherness (Kusnawan \& Rustandi, 2021).

Historically, the narrative of social tolerance with inter-religious communities can be found in the Medina Charter. The Medina Charter became authentic evidence as a regulation (qanun) that bound the various interests of the three religious groups, namely Islam, Judaism, and Magian. The Prophet Muhammad carried out the da'wah agenda through peaceoriented negotiations through this charter. In this case, negotiations become a means of building harmony and harmony among religious communities. It contains the values of togetherness based on humanity's spirit. Negotiations are carried out through a humanist approach and interactive dialogue. Thus, it can glue social cohesiveness among a multicultural society (Rustandi \& Sahidin, 2019).

Rasulullah SAW taught the importance of carrying out a social 
da'wah approach by applying the principles of brotherhood, equality, tolerance, mutual assistance, and justice (Basri, 2015). This da'wah pattern is carried out mainly against external objects outside of Muslims. Social da'wah is carried out with a collectivity approach and collaborative da'wah that emphasizes human tolerance and the application of morality as part of a social group. This can be done either through cultural approaches, interactive dialogue, social advocacy, peace education, and so on. So that in the end, awareness of tolerance, humanization, transcendence, and liberation within the scope of the plurality of society is built as an object and field of da'wah (Rustandi \& Sahidin, 2019).

\section{Patterns of Religious Harmony}

Harmony itself is not yet the final value but is only a means that must exist as a "condition sine qua non" to achieve a further goal, namely a safe and peaceful situation. This situation is urgently needed by all parties in society to create spiritual and material values to achieve a higher level of life (Umar \& Hakim, 2019). In the context of Indonesia, religious harmony can be formed when the culture of the community can create a means of meeting outside the context of religion.

It is necessary to preserve the natural arena of religious interaction in this position. Namely, an interactive space that grows from the awareness of religious people to blend in with other religious groups, not because of forced interactions. Approaches that may be rationally taken to restore harmony are through cultural, institutional, and government approaches, cooperation between religious leaders and the community, and community cooperation between religious communities themselves (Suhasran, 2018).

The dynamics of religious tolerance and harmony in the city of Semarang have internal challenges. The challenge is related to the view that traditional values carried out by religious people may be judged to pollute the purity of religious teachings. Certain traditional traditions contain the value of shirk, so religious teachings need to be purified like the source (Ismail, 2010). In addition, the pattern of religious harmony is also influenced by the existence of Javanese cultural values, such as mutual respect (tolerance), respect for differences, appreciation, and respect for ancestral spirits, togetherness embodied in community service activities or cooperation, sincere and sincere, love peaceful, non-discriminatory, open to external values and consistent (Fidiyani, 2013).

The pattern of religious harmony based on the center of harmony, 
local traditions, religious teachings, religious leaders, and community and government institutions can be seen in Figure 2 below.

Figure 2. Patterns of Harmony in Central Java

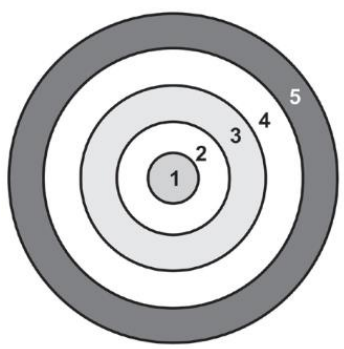

1. Pusat Kerukunan

2. Tradisi Lokal

3. Ajaran Agama

4. Tokoh Agama

5. Kelembagaan Masyarakat/Pemerintah

Source: Ismail, 2010

Based on Figure 2 above, it can be explained that the pattern of religious harmony in Indonesia can be categorized into two patterns, namely: First, religious pluralism, which is based on the assumption that the source of conflict that has occurred in Indonesia This is because of the truth claim of each religion. For this reason, it is necessary to harmonize the views of all religious adherents that, in essence, all religions are the same. A plurality of beliefs as an integral part of the social conditions of Indonesian society has not been fully understood and believed by some religious communities (Ulinnuha, 2021). Second, religious non-pluralism is a pattern of opposition to religious pluralism. This pattern recognizes that diversity or plurality is necessary and cannot be denied but does not recognize that all religions are the same (Manshuruddin, 2017).

The pattern of religious harmony in the city of Semarang develops because of cooperation, accommodation, and tolerance (Fahham, 2018). This can be seen through various activities that lead to an awareness of plurality on the personal, communal and institutional sides. Activities that bring together religious adherents are intensively organized in various forums and interaction spaces. Thus, by itself strengthen tolerance and harmonization of society.

The pattern of safety-oriented harmony is manifested in three forms - first, the internal harmony of religious communities. Where every religious believer has their activities, the goal is to strengthen the solidarity of fellow members. Second, inter-religious harmony is manifested in commemorating holidays, social, and political, such as in the election of hamlet heads. And third, inter-religious harmony with the government. 
This is done by strengthening synergies that are manifested in regulations that regulate social harmony (Riady, 2019).

\section{Effective Leadership in Semarang City}

The roles and positions of government figures, religious leaders, and community leaders appear prominent in guiding, directing, and providing solutions in a difference of opinion or a clash of "interests," which is seen as disturbing the harmonious life between religious communities. The Semarang City Government is also always co-ordinating and accommodating in matters concerning the interests of the general public, especially religious matters. Conducive life in the city of Semarang until now, more because government figures, religious leaders, and community leaders can be used as good role models for the community. They mainly concern policies in the implementation of religious harmony.

The success of a leader is very dependent on the existence of an exemplary attitude, being able to encourage and provide encouragement to those being led. This leadership pattern is effective. Madyo Ekosusilo (1996: 7; See also Malayu, 2001: 168) states that the principle of effective leadership can refer to the functional principle of leadership initiated by $\mathrm{Ki}$ Hajar Dewantara, namely "ing ngarso sung tulodho, ing madyo mangun karso, tut wuri handayani."

Ing ngarso sung tulodho means that a leader must make himself a role model. This is done through his attitudes and actions that inspire the people he leads. Ing madyo mangun karso means that the leader must arouse the spirit of initiative and creativity in the people he leads. Tut wuri handayani means a leader must be able to encourage the people he leads to daring to walk in front and take responsibility.

Effective leadership in Semarang is seen as able to encourage the strengthening of harmonization and social cohesiveness between religious communities. In this case, the leaders' success in Semarang is because the leaders can grow national insight to the people and their followers. Strengthening national insight will make all citizens aware of the importance of living together based on equal status and rights before the law. This will ensure the peaceful life of the entire nation. Equality of status and human rights is the basis of all law rules. This is what the majority party needs to enforce equal status and rights within the internal environment of each group, including the ethnic or religious majority itself.

Growing awareness of the need for national insight can touch the 
core nature of human life. That is about rationally different interests. The process of forming a life together requires a willingness to go back and forth and give and take each other. In essence, being willing to sacrifice for the interests of fellow citizens will also mean protecting the interests of each. That way, awareness will probably grow in a reasonably national solid perspective. This awareness will grow if an understanding can be developed that the ability to maintain the uniqueness of a group can only be developed in togetherness with other groups.

In national life, religious harmony is realized because of religious pluralism and democratic attitudes. These two attitudes were developed by the leaders in the city of Semarang. The pattern of developing harmonious relations between religious communities is not only focused on efforts to eliminate conflict, but living together peacefully is an ideal goal in religious, social interaction.

In addition, dialogue between religious leaders mediated by the government in Semarang City has a strategic meaning, namely as a common starting point in solving universal humanitarian problems from the perspective of religions. In this religious atmosphere, pluralism is no longer seen as a threat but as a potential in building a better national life. The example of leaders, both state and religious leaders, will strengthen social solidarity. This is seen as impacting the harmony of life in a pluralistic society.

The da'wah perspective views exemplary as a dimension of Islamic mercy. Where exemplary is categorized as a method of preaching wisdom that strengthens Islamic da'wah efforts in a charitable manner (Zaini, 2017). Exemplary as an effective da'wah effort in internalizing Islamic teachings. As exemplified by the Messenger of Allah in the da'wah period in Medina, who put forward exemplary in conveying the message of Islam. At that time, the Prophet Muhammad manifested as a religious leader and a state that served all the people of Medina. Theologically, the Prophet Muhammad saw as a preacher and spiritual leader of Muslims who internalized Islamic teachings. Sociologically, the Prophet Muhammad was seen as a state leader who led Muslims and all heterogeneous groups of people in Medina (Rustandi \& Sahidin, 2019).

This practical leadership leads to understanding and agreement to live above differences, to build cooperation and social solidarity, without mixing religious teachings and forcing each other's will. In this way, interreligious harmony can be developed through intensive communication and 
dialogue, simultaneous social interaction in various forms of social and cultural action, strengthening the development of multicultural awareness, strengthening national insight, and exemplary leadership that can raise the spirit of togetherness. In the da'wah perspective, the pattern of social da'wah is an alternative in building tolerance and harmonization to create cooperation, accommodation, openness, mutual respect, respect, compassion, peace, and mutual help as plural and multicultural society that stands on common interests. This da'wah pattern displays the spirit of rahmatan lil alamin.

\section{CONCLUSION}

The city of Semarang, a religious community, always maintains harmonious relations between religious adherents and has an attitude of understanding each other in differences. This is shown in everyday social life as well as in religious celebrations. There has never been a conflict. If a conflict arises, it can be resolved with entire kinship and mutual understanding without being followed by something that creates vulnerability and riots.

Harmony between religious communities is built in people's daily lives in the city of Semarang. This can be seen from cooperation, accommodation, and tolerance, which leads to social harmonization. In addition, strengthening the values of moderation in the form of openness, equality, deliberation, mutual respect, and mutual respect for differences is a force that can build solidarity and social cohesiveness. The development of this harmony is the responsibility of all parties to realize it through a process of social interaction and integration. The leadership role that provides good examples from government leaders, religious leaders, and community leaders strengthens the building of religious harmony in the city of Semarang. This is the strength of Islamic da'wah to build tolerance, humanization, transcendence, and liberation in social relations.

The development of inter-religious harmony can be carried out through intensive communication and dialogue, simultaneous social interaction in various forms of social and cultural action, strengthening the development of multicultural awareness, strengthening national insight, and exemplary leadership that can raise the spirit of togetherness. In the da'wah perspective, the pattern of social da'wah is an alternative in building tolerance and harmonization to create cooperation, accommodation, openness, mutual respect, respect, compassion, peace, and mutual help as 
Siti Prihatiningtyas, Siti Solihati \& Lukmanul Hakim

plural and multicultural society that stands on common interests. This da'wah pattern displays the spirit of rabmatan lil alamin.

\section{REFERRENCES}

Akhmadi, A. (2019). Moderasi Beragama Dalam Keragaman Indonesia Religious Moderation in Indonesia' S Diversity, Inovasi: Jurnal Diklat Keagamaan, 13(2), 45-55. https://bdksurabaya.ejournal.id/bdksurabaya/article/view/82.

Arafah, S., \& Basman, B. (2021). The Harmony Of Religious People Perspetive Of Christian Group: Intra And Inter-Religious Relations In Ambon. https://doi.org/10.4108/eai.2-11-2020.2305076

Aripudin, A. (2013). Sosiologi Dakwah. Bandung: Rosda Karya.

Aripudin, A., \& Sambas, S. (2012). Dakwah Antar Budaya. Bandung: Remaja Rosda Karya.

Basri, H. (2015). Manajemen Dakwah Nabi Saw di Madinah, Jurnal AlMunzir, 8(2), 179-196. https://ejournal.iainkendari.ac.id/almunzir/article/view/743.

Busyro, Aditya, H. A., \& Adlan S. T. (2019). Moderasi Islam Wasathiyyah) di Tengah Pluralisme Agama Indonesia, Jurnal Fuaduna, 3(1).

Dachlan, M., Noviani, N., \& Mustolehudin. (2018). Building Harmony Through Religious Counseling, Esensia, 19(1), 117-128. DOI: 10.24235/tamaddun.v7i2.5503.g2562. .

Fahham, A. M. (2018). Dinamika Hubungan Antarumat Beragama: Pola Hubungan Muslim Dan Hindu Di Bali, Jurnal Aspirasi, 9(1), 63-82. https://doi.org/10.22212/aspirasi.v7i1.1084

Fidiyani, R. (2013). Kerukunan Umat Beragama di Indonesia (Belajar Keharomonisan dan Toleransi Umat Beragama Di Desa Cikakak, Kec. Wangon, Kab. Banyumas), Jurnal Dinamika Hukum, 13(3), 468482. Retrieved from http://dinamikahukum.fh.unsoed.ac.id/index.php/JDH/article/vie $\mathrm{w} / 256$

Hadi, R. (2016). Pola Kerukunan Umat Beragama di Banyumas, IBDA': Jurnal Kajian Islam Dan Budaya, 14(1), 66-78.

Imron, H. S. A. (2011). Kearifan Lokal Hubungan Antara Umat Beragama Di Kota Semarang, Riptek, 5(I), 7-18.

Ismail, A. (2010). Refleksi Pola Kerukunan Umat Beragama (Fenomena Keagamaan di Jawa Tengah, Bali, dan Kalimantan Barat), Analisa, 17(2), 175-186. 
Kosasih, E. (2019). Literasi Media Sosial dalam Pemasyarakatan Sikap Moderasi Beragama, Jurnal Bimas Islam, 12(1), 263-296. https://doi.org/10.37302/jbi.v12i2.118.

Kusnawan, A., \& Rustandi, R. (2021). Menemukan Moderasi Beragama dalam Kaderisasi Dakwah: Kajian pada Pemuda Persatuan Islam Jawa Barat, Nalar: Jumal Pemikiran dan Peradaban Islam, 5(1), 41-61. DOI: https://doi.org/10.23971/njppi.v5i1.2900.

Liliweri, A. (2005). Prasangka dan Konflik; Komunikasi Lintas Budaya Masyarakat Multikultur. Yogyakarta: LKIS Yogyakarta.

Manshuruddin. (2017). Perspektif Forum Kerukunan Umat Beragama (FKUB) Sumatera Utara, Miqot: Jurnal Ilmu-ilmu Keislaman, 41(2), 477495.

http://jurnalmiqotojs.uinsu.ac.id/index.php/jurnalmiqot/article/vi ew/400

Marzuki. (2016). Pluralitas Agama dan Kerukunan Umat Beragama di Indonesia (Mencari Peran Pendidikan Agama di Perguruan Tinggi Umum), Cakrawala Pendidikan: Jurnal Ilmiah Pendidikan, 2(2), 176-186. https://doi.org/10.21831/cp.v2i2.9291

Masmuddin. (2018). Dakwah dalam Mewujudkan Interaksi dan Kerukunan Antar Umat Beragama Di Palopo Sulawesi Selatan, Komunika: Jurnal Dakwah dan Komunikasi, 12(2), 355-384. DOI: http://doi.org/10.24090/komunika.v12i2.1681.

Muhyiddin, A. Et. Al. (2014) Dakwah Perspektif al-Quran, Kajian Dakwah Multiperspektif: Teori, Metodologi, Problem, dan Aplikasi. Bandung:

Remaja Rosdakarya.

Mussafa, R. A. (2018) Konsep Nilai-nilai Moderasi dalam Al-Qur'an dan Implementasinya dalam Pendidikan Agama Islam (Analisis AlQur'an Surat Al-Baqarah ayat 143), Skripsi Fakultas Ilmu Tarbiyah dan Keguruan Universitas Islam Negeri Walisongo Semarang.

Riady, A. S. (2019). Salam, Shalom, dan Shanti: Orientasi Kerukunan Umat Beragama Di Dukuh Caben, Bantul, Dialektika: Jurnal Pemikiran Islam Dan Ilmu Sosial, 12(02), 158-167.

Rustandi, R., \& Hanifah, H. (2019). Dinamika Dakwah Komunitas Remaja Islam di Kecamatan Pangalengan, ANIDA (Aktualisasi Nuansa Ilmu Dakwah), 19(2), 199-224. DOI :10.15575/anida.v19i2.7540.

Rustandi, R., \& Muchtar, K. (2020). Analisis Framing Kontra Narasi Terorisme dan Radikalisme di Media Sosial (Studi Kasus pada Akun (a)dutadamaijabar), Komunikatif: Jurnal Ilmiah Komunikasi, 9(2), 134- 
152.

Rustandi, R., \& Sahidin, S. (2019). Analisis Historis Manajemen Dakwah

Rosulullah Saw dalam Piagam Madinah, Tamaddun: Jurnal Sejarah dan Kebudayaan Islam, 7(2), 362-387. https://www.syekhnurjati.ac.id/jurnal/index.php/tamaddun/article /view/5503.

Sabara. (2019). Potret Kerukunan Umat Beragama Berbasis Kearifan Lokal di Desa Ohoidertawun, Kabupaten Maluku Tenggara, Jurnal Penamas, 32(2), 427-444.

Sabarudin., \& Arif, M. (2019). Kerukunan Hidup Antar Umat Beragama Berbasis Kearifan Lokal Studi Kasus di Kampung Loloan Kab. Jembrana Provinsi Bali, Jurnal Sosiologi Reflektif, 14(1), 1-28. http://ejournal.uin-

suka.ac.id/isoshum/sosiologireflektif/article/view/1722.

Setiawati, N. (2012). Tantangan Dakwah dalam Perspektif Kerukunan Antar Umat Beragama, Jurnal Dakwah Tabligh, 13(2), 259-267. http://journal.uin-

alauddin.ac.id/index.php/tabligh/article/view/308.

Sila, M. A., \& Fakhruddin. (2020). Indeks Kerukunan Umat Beragama 2019, Balai Penelitian dan Pengembangan Agama Makassar, Vol. 19.

Suhasran, S. (2018). Pola Kerukunan Umat Beragama di Kabupaten Soppeng. Retrieved from http://repositori.uinalauddin.ac.id/id/eprint/13520

Suryana, T. (2011). Konsep dan Aktualisasi Kerukunan antar Umat Beragama. Jurnal Pendidikan Islam Ta’lim, 9(2), 127-136. Retrieved from http://jurnal.upi.edu/file/03_KONSEP_ DAN_AKTUALISASI_KERUKUNAN_ANTAR_UMAT_ BERAGAMA_-_TOTO.pdf.

Ulinnuha, R. (2021). Religious Exclusivity, Harmony and Moderatism amid Populism: A Study of Interreligious Communication in West Sumatra, Esensia: Jurnal Ilmu-Imu Ushuluddin, 22(1), 115. https://doi.org/10.14421/esensia.v22i1.2816

Umar, U., \& Hakim, M. A. (2019). Hubungan Kerukunan Antara Umat Beragama Dengan Pembentukan Perilaku Sosial Warga Perumahan PT Djarum Singocandi Kudus, Jurnal Penelitian, 13(1), 71. https://doi.org/10.21043/jp.v13i1.4898

Wahab, A. J. (2019). Model Kerukunan Umat Beragama di Dusun Susuru, Alqalam, 36(1), $1-20 . \quad$ DOI: 
http://dx.doi.org/10.32678/alqalam.v36i01.566.

Yusrina, J. A., \& Ma'arif, S. (2020). Islam and Tolerance: The Educational Pattern of Community in Kutuk Village, Kudus, Analisa: Journal of Social Science and Religion, 5(02), 235-250. https://doi.org/10.18784/analisa.v5i02.1140

Zaini, A. (2017). Dakwah dan Pemberdayaan Masyarakat Perdesaan, Jurnal Ilmu Dakwah, 37(2), 284-301. DOI: 10.21580/jid.v37.2.2708. 
